2021:6(6):210-218

http://ojs.uho.ac.id/index.php/JIA

doi: http://dx.doi.org/10.37149/JIA.v6i6.21245

\title{
SISTEM PEMASARAN JERUK SIAM GUNUANG OMEH DENGAN PENDEKATAN STRUCTURE, CONDUCT, PERFORMANCE (SCP) DI KABUPATEN LIMA PULUH KOTA
}

\author{
Mega Amelia Putri ${ }^{*{ }^{*}}$, John Nefri ${ }^{11}$ dan Rahma Dini ${ }^{1)}$ \\ ${ }^{1}$ Program Studi Pengelolaan Agribisnis Jurusan Budidaya Tanaman Pangan \\ Politeknik Pertanian Negeri Payakumbuh
}

*Corresponding author: lia.politani@gmail.com

To cite this article:

Putri, M., Nefri, J., \& Dini, R. (2021). Sistem Pemasaran Jeruk Siam Gunuang Omeh dengan Pendekatan Structure, Conduct, Performance (SCP) di Kabupaten Lima Puluh Kota. JIA (Jurnal Ilmiah Agribisnis) : Jurnal Agribisnis dan IImu Sosial Ekonomi Pertanian, 6(6), 210 - 218. doi:http://dx.doi.org/10.37149/jia.v6i6.21245

Received: October 21, 2021; Accepted: December 30, 2021; Published: December 31, 2021

\begin{abstract}
Gunuang Omeh sub-district is the center of jeruk siam production because it has superior ranges of citrus based on the Mandate of the Minister of Agriculture in 2008. This location has the most extensive variety of farmers, particularly $70.5 \%$ (987 farmers). Presently, the asking price of oranges from this location is $69.23 \%$ higher than rivals from outside the area. The role of various other marketing establishments is fairly more leading in determining prices than farmers. This research aims to analyze the marketing of Jeruk Siam Gunuang Omeh with a Structure, Conduct, and Performance (SCP) approach. This research was conducted in Kenagarian Koto Tinggi in August 2019 and January 2020. The information used was secondary data and primary. Farmers were selected through purposive sampling and snowball sampling for a middleman. Information processing in this study used qualitative and quantitative detailed evaluation. Based upon the assessment of the market structure, jeruk siam marketing tends to lead to an oligopsony market framework. Going by market habits, there are four marketing channels and marketing functions performed by marketing establishments, mainly the exchange function, physical facility function, and function. On the other hand, market performance evaluation shows that the share of prices received by farmers (farmer's share) is relatively high (\&gt; $40 \%)$. This is because of the lack of various other marketing establishments that execute the processing of jeruk siam. There's no considerable increase in item included worth between marketing firms
\end{abstract}

Keywords: farmer's share; margin; SCP Approach; value added

\section{PENDAHULUAN}

Di Indonesia, jeruk siam merupakan satu diantara macam buah-buahan yang teramat banyak dikembangkan serta ditebarluaskan. Menurut (Badan Pusat Statistik, 2018a) mengatakan bahwa total produksi jeruk siam di Indonesia menduduki peringkat ke tiga setelah pisang dan mangga, dengan total produksi sebanyak 2,4 juta ton. Kabupaten Lima Puluh Kota menjadi sentra produksi jeruk siam di Sumatera Barat. Varietas jeruk yang dikembangkan adalah Jeruk Siam Gunuang Omeh (JESIGO). Alasan pemilihan nama ini dikarenakan jeruk siam gunuang omeh dibudidayakan di Kecamatan Gunuang Omeh. Kecamatan Gunuang Omeh merupakan daerah dengan kontribusi jeruk siam paling besar di Kabupaten Lima Puluh Kota jika dibandingkan dengan kecamatan lainnya yaitu sebesar 95,37\% dari keseluruhan total produksi pada tahun 2015 (7.848,1 ton) (Badan Pusat Statistik, 2018b)

Kenagarian Koto Tinggi merupakan daerah dengan persentase jumlah petani terbanyak yaitu sebesar 70,5 persen (987 petani). Total luas lahan yang ditanami jeruk sebanyak 42,75 persen $(388,64$ hektar). Hal ini menunjukkan bahwa struktur ekonomi di Kenagarian Koto Tinggi sebagian besar bertumpu pada sektor perkebunan jeruk. Besarnya tingkat produksi jeruk siam di Kecamatan Gunuang Omeh juga harus diimbangi dengan pemasaran yang baik. Menurut (Gisti et al., 2018) salah satu permasalahan yang dihadapi komoditas ini adalah fluktuasi harga. Saat ini harga jual jeruk siam relatif lebih mahal $69,23 \%$ dari produk pesaing. Tingginya harga jual akan berdampak terhadap lembaga pemasaran yang terlibat. (Nilayani et al., 2021) menyatakan bahwa faktor penghambat bagi 
petani antara lain adanya penurunan harga jeruk secara drastis akibat terjadinya panen raya, selain itu kondisi harga jeruk yang tidak menentu menjadi resiko tersendiri bagi petani tertutama akibat tidak seimbangnya pengeluaran untuk pembelian beberapa faktor produksi seperti pupuk dan ongkos perawatan. Oleh karena itu, pemasaran jeruk siam memerlukan suatu pendekatan khusus untuk mampu mengantisipasi ketidakstabilan harga dan keterlibatan setiap lembaga pemasaran dalam mempengaruhi suatu harga yang terbentuk.

Pendekatan yang bisa dipakai dalam mempelajari metode pemasaran adalah lewat pendekatan Structure, Conduct, Peformance (SCP). SCP digunakan untuk menganalisa kondisi pemasaran dengan menguraikan kondisi struktur pasar, perilaku pasar atau keragaan pasar pada tiap lembaga pemasaran yang terlibat. Keuntungan dari pendekatan SCP ini adalah dapat menganalisis sistem pemasaran secara lebih kompleks karena terdapat keterkaitan antara satu sistem dengan yang lainnya (Panagiotou, 2006), selain itu pendekatan ini merupakan pendekatan agregat dari keseluruhan karakteristik, jenis-jenis pasar, perilaku dan sistem pasar (Kohls \& Uhl, 2002). Penelitian pemasaran dengan pendekatan SCP telah diterapkan pada komoditas pertanian, seperti tanaman pangan, perekebunan, perikanan maupun industri pengolahan produk pertanian (Amalia \& Firmansyah, 2021; Arthatiani et al., 2020; Hardianti et al., 2020; Hardiyanti et al., 2020; Hopid et al., 2021; Puspitasari et al., 2020; Safitri et al., 2021; Yamin et al., 2021). Hasil riset ini memvisualisasikan jika jalinan dari ke-3 faktor itu ialah jalinan linier di mana struktur memengaruhi perilaku dan memengaruhi performa.

Permasalahan pemasaran yang sering dihadapi oleh produk pertanian yaitu terkait fluktuasi harga (Hardianti et al., 2020), panjangnya rantai pemasaran (Amalia \& Firmansyah, 2021), kondisi produk yang mudah rusak (Marhawati et al., 2021), keterbatasan informasi pasar (Amanta, 2019) dominasi salah satu lembaga pemasaran dalam proses penentuan harga (Kausadikar et al., 2019; Putri et al., 2013). Oleh karenanya, pendekatan struktur, perilaku dan kinerja akan memberikan gambaran secara komprehensif terkait kondisi pemasaran suatu komoditas pertanian. Riset ini mempunyai tujuan untuk menganalisa keadaan struktur pasar, perilaku pasar dan kinerja pasar pada pemasaran jeruk siam Gunuang Omeh.

\section{MATERI DAN METODE}

Lokasi riset di Kenagarian Koto Tinggi, Kecamatan Gunuang Omeh, Kabupaten Lima Puluh Kota, Propinsi Sumatera Barat sebagai sentral produksi jeruk siam. Keseluruhan komunitas petani ialah 987 petani. Contoh petani diputuskan secara menyengaja (purposive sample) sekitar 20 orang, Petani yang dipilih yaitu petani yang mempunyai jumlah pohon jeruk siam produktif sedikitnya 250 batang. Lembaga pemasaran diputuskan dengan tehnik snow ball, dengan ikuti jalur pemasaran yang berada di Kenagarian Koto Tinggi. Lembaga pemasaran yang turut serta diantaranya pedagang pengepul sekitar delapan orang, pedagang retail dalam wilayah sekitar delapan orang dan retail luar wilayah sekitar tiga orang. Waktu riset dilaksanakan di bulan Agustus 2019 sampai Januari 2020.

Analisis pemasaran JESIGO dilakukan dengan pendekatan struktur (structure), perilaku (conduct) dan kinerja (performance) pemasaran yang biasa disingkat SCP. Metode analisis dilakukan secara deskriptif kuantitatif. Metode deskriptif digunakan untuk mendeskripsikan saluran pemasaran, lembaga pemasaran, fungsi-fungsi pemasaran dan perilaku pasar yang terjadi dalam pemasaran JESIGO. Metode kuantitatif digunakan untuk menganalisis biaya - biaya pemasaran, margin pemasaran, dan farmer share.

\section{Analisis Struktur Pasar}

Menurut (Dahl \& Hammond, 1977) struktur pasar adalah satu dimensi yang memperjelas pengambilan keputusan oleh perusahaan ataupun industri baik dari segi pengaturan pasar dan strategi perusahaan. (Kohls \& Uhl, 2002) menambahkan struktur pasar dapat diukur melalui analisis pangsa pasar, konsentrasi pasar dan juga hambatan masuk pasar.

\section{a. Pangsa Pasar (market share)}

Pangsa pasar diukur menggunakan rasio antara jumlah pembelian JESIGO oleh pedagang pengepul terhadap total transaksi pembelian JESIGO di Kenagarian Koto Tinggi. Pemilihan pedagang pengepul dikarenakan pada lembaga pemsasaran ini tingkat pengumpulan pasar terbesar diantara semua lembaga pemasaran. Analisis perhitungan sebagai berikut:

$$
\text { MSpi }=\frac{\text { Spi }}{\text { Stot }} \times 100 \%
$$


Dimana: $\mathrm{MS}_{\mathrm{pi}}$ : Pangsa pasar pedagang pengepul ke-i (\%), $\mathrm{S}_{\mathrm{pi}}$ : Pembelian pedagang pengepul ke-i (Kg/minggu), $S_{\text {tot }}$ : Total transaksi pembelian seluruh pedagang pengepul $(\mathrm{Kg} / \mathrm{minggu})$

b. Konsentrasi Pasar

Konsentrasi pasar dapat diketahui dari empat pembeli terbesar (CR4) dengan perhitungan sebagai berikut:

$$
\mathrm{CR}_{4}=\mathrm{S}_{1}+\mathrm{S}_{2}+\mathrm{S}_{3}+\mathrm{S}_{4}
$$

Dimana: $\mathrm{CR}_{4}$ : Concentration Ratio for The Biggest Four $(\%), \mathrm{S}_{1}$ : Jumlah pembelian JESIGO, Pengepul 1 (Kg/Minggu), $S_{2}$ : Jumlah pembelian JESIGO Pengepul 2 (Kg/Minggu), $S_{3}$ : Jumlah pembelian JESIGO Pengepul 3 (Kg/Minggu), $S_{4}$ : Jumlah pembelian JESIGO Pengepul 3 (Kg/Minggu). Kriteria pengambilan keputusan, Pujiharto (2014): Jika nilai $\mathrm{CR}_{4} \leq 33 \%$ (competitive marjet structure), Jika nilai $\mathrm{CR}_{4}$ berkisar antara 33\%-50\% (weak oligopsonist market structure), Jika nilai $\mathrm{CR}_{4}>50 \%$ (strongly oligopsonist market structure)

\section{c. Hambatan Masuk Pasar}

Minimum Efficiency Scale (MES) adalah sinyal yang dipakai buat menghitung rintangan/ kendala masuk pasar. Menurut (Carlton \& Perlof, 2000) jika nilai MES dapat dihitung dengan membandingkan nilai rata-rata output empat pedagang pengepul JESIGO terbesar terhadap output total keseluruhan pedagang pengepul.

$$
\text { MES }=\frac{\text { Rata-rata Output } 4 \text { Pedagang Pengepul Terbesar }}{\text { Output Total }}
$$

\section{Analisis Perilaku Pasar}

Perilaku pasar menggambarkan secara deskriptif atas fenomena yang ditemukan di lapangan dalam aktivitas pemasaran JESIGO. Menurut (Dahl \& Hammond, 1977) beberapa karakter perilaku pasar salah satunya taktik penetapan harga, kegiatan pembelian dan pemasaran, koordinir antara instansi proses pembayaran. Tiap perilaku ini mempunyai keterikatan satu sama lainnya. Ini memvisualisasikan jika sikap pasar sebagai sikap simpatisan (konsumen dan penjual) dalam jalinan bersaing atau perundingan pada simpatisan yang lain untuk menggapai arah pemasaran dalam struktur pasar tertentu.

\section{Analisis Kinerja Pasar}

Kinerja pasar sebagai gabungan antara struktur dan perilaku pasar yang menunjukkan terjadi jalinan antara struktur, perilaku dan kinerja pasar yang tidak selama-lamanya linear tetapi mempengaruhi. Kinerja pasar JESIGO di Kenagarian Koto Tinggi diukur memakai margin pemasaran, dan farmer's share.

\section{a. Margin Pemasaran}

Analisis margin pemasaran dipergunakan untuk menganalisis pemasaran produk mulai dari produsen sampai dengan konsumen. Margin yaitu ketidaksamaan harga yang dibayar konsumen pada harga yang diterima oleh produsen (Kohls \& Uhl, 2002). Makin tinggi biaya pemasaran mengakibatkan makin tingginya marketing margin. Secara matematis bisa dicatat seperti berikut:

$$
M_{m}=P_{r}-P_{f}
$$

Dimana: $M_{m}$ : Margin pemasaran JESIGO, $P_{r}$ : Harga JESIGO ditingkat konsumen $(\mathrm{Rp} / \mathrm{Kg}), \mathrm{P}_{\mathrm{f}}$ : Harga JESIGO ditingkat produsen/petani $(\mathrm{Rp} / \mathrm{Kg})$

Perbedaan margin pemasaran disebabkan oleh perbedaan perlakuan atau penanganan produk sehingga terdapat perbedaan biaya antar lembaga pemasaran. Oleh Karena it, dalam margin pemasaran ada dua bagian, ialah bagian cost serta bagian keuntungan lembaga pemasaran, jadi:

$$
\begin{aligned}
& M_{m}=c+\pi \\
& P_{r}-P_{f}=c+\pi \\
& P_{f}=P_{r}-c-\pi
\end{aligned}
$$

Dimana: c : Biaya pemasaran $(\mathrm{Rp} / \mathrm{Kg}), \pi$ : Keuntungan lembaga pemasaran $(\mathrm{Rp} / \mathrm{Kg})$ 


\section{b. Farmer's Share}

Perbandingan antara harga yang diterima petani dengan harga yang dibayarkan oleh lembaga pemasaran disebut dengan Farmer's share (Dahl \& Hammond, 1977; Kohls \& Uhl, 2002). Menurut (Kohls \& Uhl, 2002) besarnya farmer's share dipengaruhi oleh tingkat pemrosesan, biaya transportasi, keawetan produk, dan jumlah produk. Distribusi margin pemasaran disaksikan berdasar sisi harga yang didapat masing-masing lembaga pemasaran, farmer's share memiliki jalinan negatif dengan margin pemasaran hingga makin tinggi margin pemasaran, karena itu sisi yang didapat petani makin rendah. Rumus yang dipakai untuk hitung farmer's share ialah seperti berikut :

$$
\mathrm{Fs}=\frac{\mathrm{Pf}}{\mathrm{Pr}} \times 100
$$

Dimana: Fs : Bagian harga yang diterima petani (\%), Pf : Harga ditingkat petani $(\mathrm{Rp} / \mathrm{Kg})$, $\mathrm{Pr}$ : Harga ditingkat retail/ penjual $(\mathrm{Rp} / \mathrm{Kg})$

\section{HASIL DAN PEMBAHASAN}

\section{Struktur Pasar (market structure)}

Tingkat persaingan yang terjadi dalam pemasaran JESIGO di Kenagarian Koto Tinggi dapat digambarkan melalu analisis struktur pasar. Identifikasi dilakukan dengan mengukur pangsa pasar, konsentrasi pasar, dan hambatan masuk pasar. Ketiga pengukuran ini tergambarkan bentuk pasar yang terjadi dalam pemasaran JESIGO.

\section{a. Pangsa Pasar}

Pangsa pasar (market share) menggambarkan sejauh mana suatu perusahaan/lembaga pemasaran menguasai suatu pasar (Panagiotou, 2006). Penelitian ini menggunakan pendekatan dari sisi kemampuan lembaga pemasaran melakukan pembelian jeruk siam dari petani. Lembaga pemasaran yang dipilh adalah pedagang pengepul. Hal ini disebabkan pengepul memiliki kekampuan (modal) yang besar untuk membeli jeruk siam dari produsen. Pangsa pasar 8 lembaga pemasaran (pedangang pengepul) JESIGO di Kenagarian Koto Tinggi dapat dilihat pada Tabel 1.

Tabel 1. Pangsa pasar delapan lembaga pemasaran jeruk siam, Tahun 2020

\begin{tabular}{cccc}
\hline No & Nama & $\begin{array}{c}\text { Rata-Rata Volume Pembelian JESIGO } \\
\text { (Kg/Minggu) }\end{array}$ & $\begin{array}{c}\text { Pangsa Pasar } \\
(\%)\end{array}$ \\
\hline 1 & Pengepul 1 & 13.000 & 15,02 \\
2 & Pengepul 2 & 14.000 & 16,18 \\
3 & Pengepul 3 & 13.000 & 15,02 \\
4 & Pengepul 4 & 12.000 & 13,87 \\
5 & Pengepul 5 & 7.500 & 8,67 \\
6 & Pengepul 6 & 9.000 & 10,40 \\
7 & Pengepul 7 & 10.000 & 11,56 \\
8 & Pengepul 8 & 8.000 & 9,24 \\
\hline & Jumlah & 86.500 & 100,00 \\
\hline
\end{tabular}

Sumber: Data diolah (2020)

Tabel 1 menunjukkan lembaga pemasaran (perusahaan) yang memiliki pangsa pasar terbesar adalah Pengepul 2 (16,18\%), selanjutnya diikuti oleh Pengepul 1 dan $3(15,02 \%)$ serta Pengepul 4 (13,87\%). Keempat perusahaan ini merupakan lembaga pemasaran ditingkat pedagang pengepul. Pangsa pasar memberikan gambaran sejauh mana pelaku mampu menguasai pasar. Pada komoditas pertanian secara personal/ organisasi, pelaku pemasaran dapat menguasau pangsa pasar tertinggi berkisar antara 15 sampai 25 persen ((Amalia \& Firmansyah, 2021; Marhawati et al., 2021; Puspitasari et al., 2020).

\section{b. Konsentrasi Pasar}

Berdasarkan pangsa pasar, konsentrasi pasar bisa dijumpai dengan hitung CR4 (Concentration Ratio for The Bigest Four). Menurut (Cramer, 2009), CR4 sebagai penjumlahan market share empat perusahaan paling besar dari satu daerah pasar. Penghitungan CR4 nanti akan memvisualisasikan struktur pasar dari pihak pembeli. Pendekatan $\mathrm{CR}_{4}$ digunakan untuk melihat persentase total input empat pedagang pengepul terbesar terhadap total input seluruh pedagang pengepul yang membeli JESIGO. 


$$
\mathrm{CR} 4=16,18 \%+15,02 \%+15,02 \%+13,87 \%=60.11 \%
$$

Berdasarkan hasil perhitungan nilai $\mathrm{CR}_{4}$ terlihat bahwa empat pedagang pengepul terbesar menguasai $60,11 \%$ dari total ketersediaan JESIGO di Kenagarian Koto Tinggi. Artinya tingkat persaingan pedagang pengepul JESIGO di Kenagarian Koto Tinggi terkonsentrasi dengan tingkat persaingan yang kecil. Hal ini menunjukkan bahwa Jeruk Siam Gunuang Omeh mengarah pada struktur pasar oligopsoni. Sejalan dengan pendapat (Kohls \& Uhl, 2002) menyatakan apabila rasio konsentrasi empat perusahaan terbesar lebih besar dari $50 \%$, maka struktur pasar cenderung berada pada kondisi ologopsoni. Pasar oligopsoni merupakan suatu kondisi pasar dimana terdapat sedikit pembeli sementara produsen yang menawarkan produknya banyak.

\section{c. Hambatan Masuk Pasar}

Kendala/rintangan masuk pasar menggambarkan segala hal yang memberi peluang terjadinya penurunan kesempatan atau kecepatan masuknya pesaing baru. Indikator yang digunakan yaitu Minimun Efficiency Scale (MES). Nilai MES diperoleh dari nilai rata-rata pembelian JESIGO 4 pedagang pengepul terbesar di Kenagarian Koto Tinggi terhadap total pembelian jesigo oleh seluruh pedagang pengepul di Kenagarian Koto Tinggi . Menurut (Putri et al., 2013) jika nilai MES lebih besar dari 10 persen mengindikasikan bahwa terdapat hambatan masuk dalam pasar JESIGO di Kenagarian Koto Tinggi.

$$
\text { MES }=5.375 / 32.000=0.15
$$

Berdasarkan perhitungan didapatkan nilai MES sebesar 15\%. Hasil perhitungan tersebut menunjukkan bahwa nilai MES lebih dari 10\% yang berarti terdapat hambatan masuk ke dalam pasar JESIGO. Hambatan utama yang dihadapi oleh pedagang pengepul JESIGO yaitu keterbatasan modal. Menurut (Sharma \& Upadhayaya, 2020) modal memiliki peran penting dalam sistem pemasaran jeruk. Banyak permasalahan pemasaran muncul karena dipicu oleh kekurangan modal (Gisti et al., 2018; Sharma \& Upadhayaya, 2020; Tijjani et al., 2019).

\section{Perilaku Pasar (Market Conduct)}

Perilaku pasar sebagai perilaku simpatisan (konsumen dan penjual) dalam jalinan bersaing atau kesepakatan antar lembaga pemsaran yang lain untuk mencapai tujuan pemasaran dalam struktur pasar tertentu. Komponen yang ada dalam perilaku pasar yakni lembaga dan praktik peranan pemasaran, mekanisme penetapan harga dan mekanisme pembayaran.

\section{a. Lembaga dan Praktik Peranan Pemasaran}

Badan usaha atau pribadi yang lakukan aktivitas atau peranan pemasaran hingga produk atau jasa akan beralih dari produsen ke konsumen dikatakan sebagai lembaga pemasaran. Adapun pihak yang terlibat dalam pemasaran JESIGO di Kenagarian Koto Tinggi meliputi, petani, pedagang pengepul dan pedagang pengecer. Masing-masing lembaga pemasaran yang terlibat melakukan fungsi-fungsi pemasaran. Petani melakukan fungsi pertukaran berupa aktivitas penjualan, sementara pedagang pengepul dan pedagang pengecer melakukan fungsi pertukaran, fungsi fisik dan fungsi fasilitas. Fungsi fisik yang dilakukan berupa pengemasan produk, dan fungsi fasilitas yang dilakukan berupa standarisasi produk seperti grading.

Namun, semua fungsi-fungsi pemasaran masih dilakukan dengan sederhana. Keterbatasan modal dan keterampilan pelaku pemasaran menyebabkan fungsi pemasaran belum berjalan maksimal. Hal ini sejalan dengan pendapat (Deshmukh et al., 2021; Sharma \& Upadhayaya, 2020; Tijjani et al., 2019) menyatakan bahwa kendala dalam sistem pemasaran jeruk antara lain adalah grading, transportasi, penjualan hasil, pengemasan dan penyimpanan. Oleh karena itu, perlu kerjasama dengan berbagai pihak terutama pemerintah daerah untuk memberikan pelatihan maupun sarana dan prasarana lainnya agak praktek fungsi pemasaran dapat dilaksanakan lebih maksimal.

\section{b. Saluran Pemasaran}

Analisa aliran pemasaran dijalankan untuk memandang perilaku tiap-tiap instansi pemasaran dalam tentukan aliran yang dipakai. Aliran pemasaran JESIGO yang terbentuk dari 20 petani responden adalah sebanyak 4 saluran. Seluruh petani responden menjual jeruk dalam bentuk buah utuh tanpa adanya proses pengolahan. Hal ini menggambarkan bahwa petani jeruk di Kengarian Koto Tinggi tidak melakukan perubahan nilai tambah terhadap jeruk yang mereka pasarkan. Rata-rata total produksi jeruk yang dihasilkan petani responden adalah 32 ton/ha per musim. 
Gambar 1 menunjukkan bahwa sebagian besar petani memasarkan produknya ke pedagang pengepul $(86,86 \%)$, yang paling sedikit yaitu pemasaran ke konsumen langsung $(5,9 \%)$. Mayoritas petani $(86,86 \%)$ menjual hasil panen mereka kepada pengepul disebabkan karena kemudahan akses pendistribusian dan jaminan pasar yang menjanjikan. Menurut (Muzuna, 2019) petani memilih menjual kepada agen/ pengepul disebabkan karena mereka tidak memiliki pilihan lain, selain itu jumlah produksi yang terbatas mengakibatkan pilihan petani menjual kepada pengepul lebih efisien dibandingkan jika petani menjual langsung kepada konsumen.

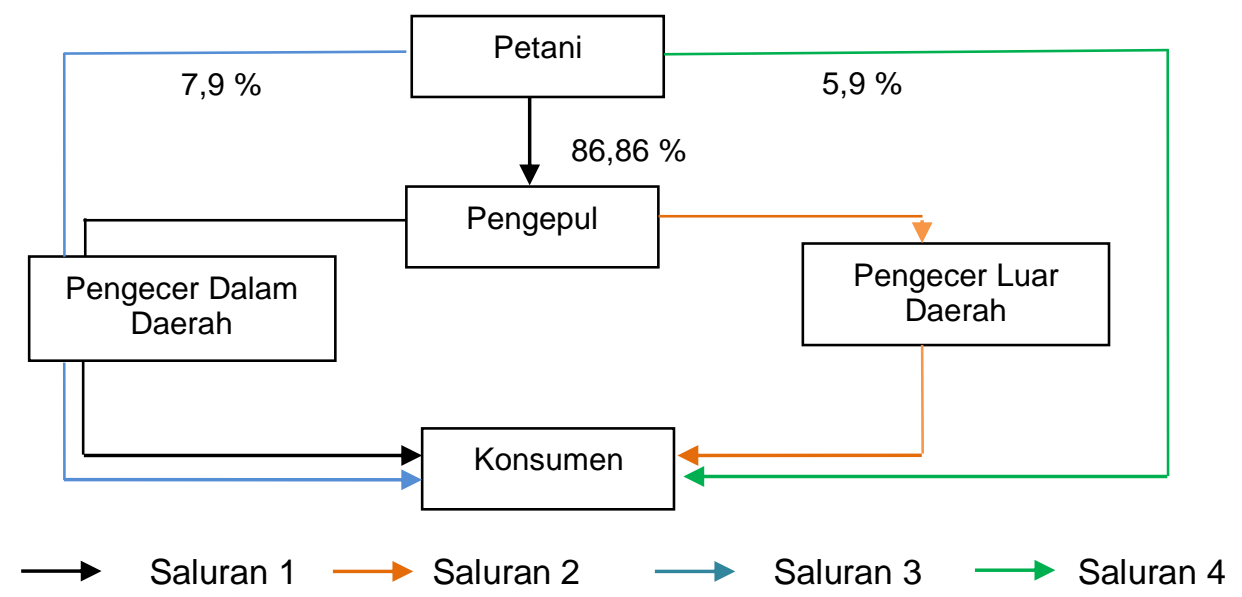

Gambar 1. Saluran pemasaran jeruk siam

c. Mekanisme Penentuan Harga

Penentuan harga JESIGO secara teknis berdasarkan pada kualitas jeruk. Hal ini meliputi bentuk dan ukuran jeruk. Bentuk yang mulus (tidak penyot dan berlubang), dan ukuran besar, sedang atau kecil. Perbedaan tersebut akan menentukan tingkat harga yang terbentuk. Selain itu, ditingkat pedagang pengepul hubungan kerjasama antar pengepul baik yang ada di daerah maupun diluar daerah memudahkan para pengepul mendapatkan informasi harga jeruk. Informasi yang diperoleh menjadi pedoman bagi pedagang pengepul dalam menentuan harga beli jeruk petani. Selain itu pengepul juga mendapatkan informasi harga dari pedagang besar provinsi dan juga dari harga pasar jeruk nasional.

Kondisi kebatasan petani dalam mendapat info harga dan ketergantungan petani dengan pedagang pengepul, mengakibatkan status tawar (bergaining position) petani jadi kurang kuat pada proses penetapan harga. Hingga supremasi pedagang pengepul dalam tentukan harga benar-benar kuat. Status petani pada pedagang pengepul hanya sebagai yang menerima harga (price taker). Hasil penelitian (Fahrunisa, 2020; Gisti et al., 2018; Hasudungan et al., 2020; Kausadikar et al., 2019) menyatakan bahwa upaya yang dapat dilakukan petani untuk meningkatkan posisi tawarnya adalah dengan memperluas pangsa pasar. Sehingga kemampuan petani dalam penentuan harga akan lebih kuat. Disisi lain pedagang pengecer yang merupakan perpanjangan tangan pedagang pengepul memperoleh informasi harga dari pedagang pengepul, sesama pengecer di pasar, dan juga dari tingkat permintaan jeruk di pasaran.

\section{b. Sistem Pembayaran}

Sistem pembayaran dalam pemasaran JESIGO di Kenagarian Koto Tinggi oleh masingmasing lembaga pemasaran sangat beragam, sesuai dengan situasi dan kondisi pada masingmasing lembaga pemasaran. Modal yang dimiliki oleh masing-masing lembaga pemasaran menjadi salah satu faktor yang mempengaruhi sistem pembayaran pada pemasaran JESIGO. Sistem pembayaran yang dilakukan dalam pemasaran JESIGO terdiri dari sistem pembayaran tunai dan sebagian/kemudian.

Pedagang pengepul biasanya memakai sistem pembayaran sebagian atau kemudian, karena pedagang pengepul membeli jeruk dalam volume yang banyak. Sistem pembayaran secara tunai biasanya dilakukan oleh pedagang pengecer, karena pedagang pengecer membeli dalam jumlah yang tidak terlalu banyak. Pedagang pengecer mampu membayar secara tunai karena perputaran modal yang terjadi di pedagang pengecer berlangsung secara cepat, hal ini disebabkan karena pengecer langsung turun ke pasar-pasar agar dapat menjangkau konsumen. 


\section{Analisis Kinerja Pasar (Market Peformance)}

Hubungan yang terjadi di antara struktur pasar dan perilaku pasar akan menggambarkan keragaan/ kinerja pasar (Panagiotou, 2006). Kinerja pasar diukur melalui margin pemasaran dan farmer's share.

\section{Margin Pemasaran}

Perhitungan margin pemasaran JESIGO dilakukan pada lembaga pemasaran pedagang pengepul dan pedagang pengecer. Analisis margin ini bertujuan untuk melihat perbedaan harga di berbagai tingkat lembaga pemasaran.

Tabel 2. Analisis margin pemasaran dan farmer's share jeruk siam, Tahun 2020

\begin{tabular}{|c|c|c|c|c|c|c|c|}
\hline \multirow{2}{*}{ No } & \multirow{2}{*}{ Uraian $(\mathrm{Rp} / \mathrm{Kg})$} & \multicolumn{6}{|c|}{ Saluran Pemasaran } \\
\hline & & 1 & $\%-S e$ & 2 & $\%-\mathrm{Se}$ & 3 & $\%-\mathrm{Se}$ \\
\hline \multirow[t]{2}{*}{1} & \multicolumn{7}{|l|}{ Petani } \\
\hline & a. Harga Jual & 8.946 & 50,52 & 8.946 & 47,09 & 10.250 & 57,99 \\
\hline \multirow[t]{11}{*}{2} & \multicolumn{7}{|l|}{ Pedagang Besar } \\
\hline & Harga Beli & 8.946 & 50,52 & 8.946 & 47,09 & - & - \\
\hline & b. Biaya Pemasaran & & & & & - & - \\
\hline & Transportasi & 240 & 1,36 & 300 & 2,27 & - & - \\
\hline & Bongkar Muat & 125 & 1,03 & 150 & 1,14 & - & - \\
\hline & Sortasi \& Grading & 166 & 1,36 & 166 & 1,26 & - & - \\
\hline & Pengemasan & 260 & 1,47 & 260 & 1,97 & - & - \\
\hline & Penyusutan & 180 & 1,48 & 180 & 1,36 & - & - \\
\hline & Harga Jual & 12.182 & 68,78 & 13.200 & 69,47 & - & - \\
\hline & Keuntungan & 3.235 & - & 4.254 & - & - & - \\
\hline & Margin Pedagang Besar & 3.235 & - & 4.254 & - & - & - \\
\hline \multirow[t]{15}{*}{3} & \multicolumn{7}{|l|}{ Pengecer } \\
\hline & a. Harga Beli & 12.182 & 68,78 & 13.200 & 69,47 & 10.250 & 57,99 \\
\hline & b. Biaya Pemasaran & & & & & & \\
\hline & Transportasi & 160 & 0,90 & 160 & 0,84 & 240 & 1,36 \\
\hline & Bongkar Muat & 125 & 0,71 & 150 & 0,79 & 125 & 0,71 \\
\hline & Sortasi \& Grading & 166 & 0,94 & 117 & 0,61 & 166 & 0,94 \\
\hline & Pengemasan & 45 & 0,25 & 45 & 0,24 & 260 & 1,47 \\
\hline & Penyusutan & 90 & 0,51 & 100 & 0,53 & 180 & 1,02 \\
\hline & Retribusi & 100 & 0,56 & 100 & 0,53 & 100 & 0,57 \\
\hline & Harga Jual & 17.710 & 100,00 & 19.000 & 100,00 & 17.676 & 100,00 \\
\hline & Keuntungan & 4.842 & & 5.128 & & 6.355 & \\
\hline & Margin Pengecer & 5.528 & & 5.800 & & 7.426 & \\
\hline & Total Biaya Pemasaran & 1.657 & 9,36 & 1.728 & 9,09 & 1.071 & 6,06 \\
\hline & Total Keuntungan & 8.078 & 45,61 & 9.382 & 49,38 & 6.355 & 35,95 \\
\hline & Total Margin & 8.764 & 49,48 & 10.054 & 52,91 & 7.426 & 42,01 \\
\hline
\end{tabular}

Hasil analisis menunjukkan bahwa margin pemasaran, biaya pemasaran dan total keuntungan terbesar terdapat pada saluran 2 (petani-pengepul-pengecer luar daerah) yaitu secara berturut-turut sebesar Rp. 10.054/Kg atau 52,91 persen, Rp. 1.728 (9,09\%) dan Rp. 9.382 (49,38\%). Hal ini dapat disimpulkan bahwa meskipun margin pemasaran pada saluran 2 tinggi namun keuntungan yang diperoleh juga tinggi, karena jeruk dipasarkan di daerah-daerah dengan tingkat daya beli konsumen lebih tinggi. Hal ini sejalan dengan hasil penelitian (Chaerani, 2021) yang menunjukkan bahwa variabel harga di tingkat konsumen dan jumlah lembaga pemasaran yang terlibat sangat berpengaruh terhadap marjin pemasaran jeruk siam.

\section{Farmer's Share}

Perbedaan di antara harga pada tingkat petani pada harga pada tingkat pedagang dimaksud yaitu Farmer's Share. Besarnya farmer's share dikontrol oleh tingkat pemrosesan, cost transportasi, keawetan produk dan jumlah produk (Kohls \& Uhl, 2002). 


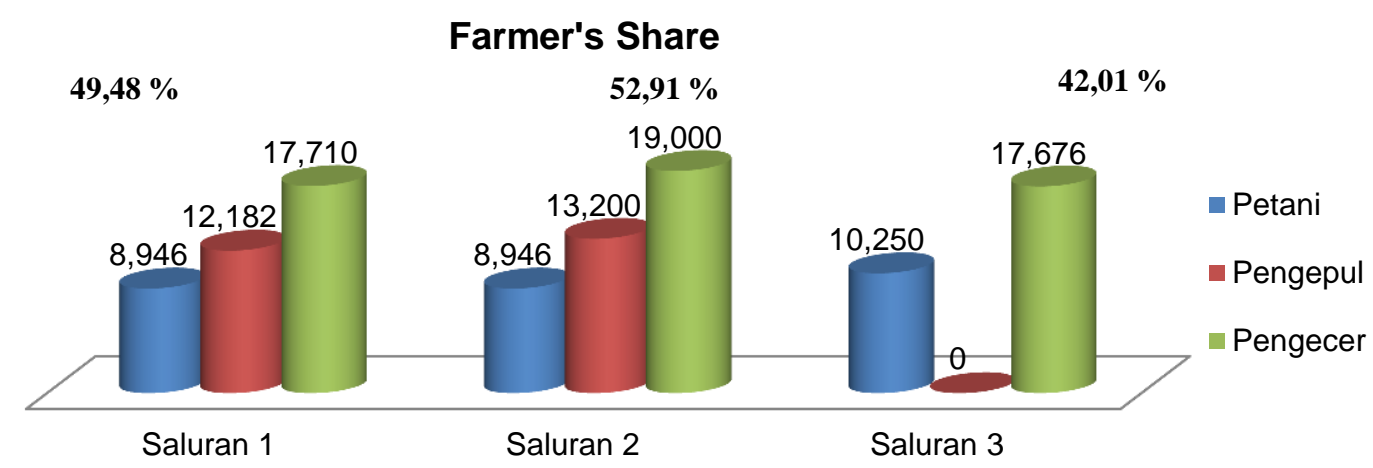

Gambar 3. Farmer's share pada Setiap Saluran Pemasaran Jeruk Siam

Sisi harga yang diterima petani termasuk tinggi. Hal Ini karena farmer's share yang diterima petani lebih dari 40\%. Searah dengan opini (Kohls \& Uhl, 2002) jika untuk aktivitas pemasaran komoditas pertanian, biasanya sisi harga yang diterima petani bisa capai $40 \%$ atau lebih dari harga yang dibayar oleh customer. Hasil riset (Hasudungan et al., 2020) dan (Nilayani et al., 2021) memperlihatkan jika sharing harga yang diterima petani jeruk siam kesemua aliran pemasaran relatif tinggi. Tingginya sisi harga yang diterima petani memvisualisasikan jika nilai jual jeruk siam relatif masih dapat dijangkau untuk konsumen dan harga yang dibayar konsumen bisa dinikmati oleh petani.

\section{KESIMPULAN DAN SARAN}

Analisis struktur pasar jeruk siam Gunuang Omeh cenderung bersifat oligopsoni. Hambatan yang terjadi berupa keterbatasan modal. Hasil analisis perilaku pasar jeruk siam Gunuang Omeh menunjukkan lembaga pemasaran JESIGO yaitu, petani, pedagang pengepul, pedagang pengecer dalam daerah, serta pedagang pengecer luar daerah. Saluran pemasaran yang terbentuk sebanyak 3 saluran pemasatan. Adapun kendala dalam fungsi pemasaran yaitu grading, transportasi dan penyimpanan. Kondisi struktur dan perilaku pasar yang terjadi mempengaruhi kinerja pasar. Analisis kinerja pasar menunjukkan bahwa, share harga jeruk siam Gunuang Omeh yang diterima petani sudah tergolong tinggi $(>40 \%)$. Pengembangan agribisnis jeruk siam di Kenagarian Koto Tinggi berpotensial untuk dikembangkan. Namun, perlu perhatian serius dari pemerintah terkait kondisi pemasaran hasil panen JESIGO yang dilakukan oleh petani. Keterbatasan petani dalam memperoleh akses sarana dan prasarana penanganan pasaca panen serta akses pasar menyebabkan belum adanya diferensiasi terhadap JESIGO yang dipasarkan.

\section{REFERENSI}

Amalia, S. A., \& Firmansyah, F. (2021). Analisis Kinerja Industri Kakao di Indonesia: Pendekatan Structure-Conduct-Performance (SCP). INDICATORS: Journal of Economics and Business, 3(2), 167-176. http://indicators.iseisemarang.or.id/index.php/jebis/article/view/78

Amanta, D. (2019). Analisis Efisiensi Saluran Pemasaran Jeruk Siam (Studi Kasus Desa Umbulsari Kecamatan Umbulsari Kabupaten Jember). Fakultas Pertanian-Peternakan, Universitas Muhammadiyah Malang. https://eprints.umm.ac.id/56817/

Arthatiani, F. Y., Suryawati, S. H., \& Kurniawan, T. (2020). Analisis Struktur, Perilaku dan Kinerja Pasar Industri Tuna di Indonesia. J.Sosek KP1, 15(1), 69-82. http://ejournalbalitbang.kkp.go.id/index.php/sosek/article/view/8343

Badan Pusat Statistik. (2018a). Produksi Buah-Buahan Nasional. Badan Pusat Statistik.

Badan Pusat Statistik. (2018b). Sumatera Barat Dalam Angka 2017.

Carlton, D. W., \& Perlof, J. M. (2000). Vertical Integration and Market Structure. Stanford University and NBER.

Chaerani, D. S. (2021). Analisis Marjin Pemasaran Jeruk Siam (Citrus nobilis Lour) di Kecamatan Pasaman Kabupaten Pasaman Barat. Jurnal Embrio, 13(1), 21-32. https://mail.ojs.unitaspdg.ac.id/index.php/embrio/article/view/679

Cramer. (2009). Agriculture Economics and Agribusiness. John Wileey and Son.

Dahl, D. C., \& Hammond, J. W. (1977). Market and Price Analysis. The Agricultural Industries. McGraw-Hill, Inc. Printed in the USA. 
Deshmukh, A., Agrawal, S., \& Jallaraph, V. (2021). Constraints Faced by Orange Growers about Production and Marketing Orange. International Journal of Agriculture, Environment and Biotechnology, 14(1), $11-16$. https://search.proquest.com/openview/450de6980489c012c2cf8685684b4302/1 ?pqorigsite $=$ gscholar \&cbl $=2032162$

Fahrunisa, F. (2020). Analisis Pemasaran Jeruk Siam (Studi Kasus di Desa PIR ADB Dusun Bamban Kecamatan Besitang Kabupaten Langkat). repository.umsu.ac.id. http://repository.umsu.ac.id/handle/123456789/14407

Gisti, S. E., Tarumun, S., \& Yusri, J. (2018). Analisis Pemasaran Jeruk Siam Gunung Omeh (Citrus nobilis lourvar) di Nagari Koto Tinggi Kecamatan Gunung Omeg Kabupaten Lima Puluh kota. Indonesian Journal of Agricultural Economics (IJAE), 9(1), 72-80. https://ijae.ejournal.unri.ac.id/index.php/IJAE/article/view/7106

Hardianti, D., Ibnusina, F., \& Alfikri, A. (2020). Seminar Nasional Virtual "Sistem Pertanian Terpadu dalam Pemberdayaan Petani." Sistem Pemasaran Gambir Dengan Pendekatan SCP (Structure, Conduct, Performance) Di Kecamatan Kapur IX, Kabupaten Lima Puluh Kota, 447-463. http://repository.ppnp.ac.id/521/

Hardiyanti, W., Wahyuni, I., \& Rahman, A. (2020). Analisis Pemasaran Cassiavera dengan Pendekatan Structure, Conduct dan Performace (SCP) di Kabupaten Kerinci. Journal of Agribusiness and Local Wisdom (JALOW), 3(2), 2621-1297. https://onlinejournal.unja.ac.id/JALOW/article/view/11618

Hasudungan, A., Tety, E., \& Eliza, E. (2020). Analisis Pemasaran Jeruk Siam (Citrus nobilis lourvar) di Desa Kuok Kecamatan Kuok Kabupaten Kampar. Indonesian Journal of Agricultural Economics (IJAE), https://ijae.ejournal.unri.ac.id/index.php/IJAE/article/view/7755

Hopid, H., Sudiyarto, S., \& Hendrarini, H. (2021). Analisis Struktur, Perilaku dan Kinerja Pasar pada Sentra Industri Rengginang Lorjuk di Kabupaten Sumenep. Jurnal Ekonomi Pertanian Dan Agribisnis (JEPA), 5(3), 787-797. https://jepa.ub.ac.id/index.php/jepa/article/view/704

Kausadikar, H. H., Nagargoje, S. R., \& Bandi, S. (2019). A Study on Price Spread and Marketing Efficiency of Sweet Orange in Nalgonda District of Telangana. Journal of Pharmacognosy and Phytochemistry, 8(4), 2248-2251. https://www.indianjournals.com/ijor.aspx?target=ijor:ijfs\&volume=9\&issue=1\&article=009

Kohls, R. ., \& Uhl. (2002). Marketing Of Agricultural Products. MacMillan Publishing Company.

Marhawati, M., Astuti, S., \& Rakib, M. (2021). Seminar Nasional LP2M UNM "Penguatan Riset, Inovasi dan Kreativitas Peneliti di Era Pandemi Covid-19." Analisis Struktur, Perilaku Dan Kinerja Pasar Jeruk Pamelo Di Kecamatan Ma'rang Kabupaten Pangkep, 774-786. https://ojs.unm.ac.id/semnaslemlit/article/view/25330

Muzuna. (2019). Analisis Pemasaran Jeruk Siam (Studi Kasus: Desa Lasembangi Kecamatan Lasalimu Kabupaten Buton). Media Agribisnis, 3(2), 93-105. http://www.jurnalumbuton.ac.id/index.php/Agribisnis/article/view/491

Nilayani, N. L., Arnawa, I. K., \& Sukanteri, N. P. (2021). Pemasaran Jeruk Siam Kintamani. AGRIMETA, 11(21), 33-38. http://e-journal.unmas.ac.id/index.php/agrimeta/article/view/2204

Panagiotou, G. (2006). The Impact of Managerial Cognitions on The Structure, Conduct, and Peformnace (SCP) Paradigm: A Strategic Group Perspective. Management Decision.

Puspitasari, A., Priyadi, R., \& Supyadi, D. (2020). Struktur, Perilaku dan Kinerja Pemasaran Cabai Rawit Merah di Kecamatan Cigalontang. AGRIBUSSINES SYSTEM SCIENTIFIC JOURNAL, 1(1), 43-55. http://jurnal.unsil.ac.id/index.php/assj/article/view/2597

Putri, M. A., Fariyanti, A., \& Kusnadi, N. (2013). Struktur dan Integrasi Pasar Kopi Arabika Gayo di Kabupaten Aceh Tengah dan Bener Meriah. Buletin RISTRI, 4(1), 47-54.

Safitri, R. P., Riana, F. D., \& Widyawati, W. (2021). Struktur, Perilaku, dan Kinerja Pasar Benih Jagung (Zea Mays L.) di Amerika Serikat, India, dan Indonesia. Jurnal Ekonomi Pertanian Dan Agribisnis (JEPA), 5(4), 1019-1036. https://jepa.ub.ac.id/index.php/jepa/article/view/751

Sharma, S., \& Upadhayaya, S. (2020). Marketing of Mandarin Orange in Jajarkot District: a Value Chain Analysis. Malaysian E Commerce Journal, 4(1), 05-08. https://doi.org/10.26480/mecj.01.2020.05.08

Tijjani, M. S., Wakawa, R. C., Goni, M., \& Bukar, A. U. (2019). Marketing of Orange Fruit in Maiduguri Metropolitan Area, Borno State, Nigeria. Journal of Biology, Agriculture and Healthcare, 9(22), 7-12. https://doi.org/10.7176/jbah/9-22-02

Yamin, F., Fariyanti, A., \& Jahroh, S. (2021). Struktur, Perilaku dan Kinerja Pemasaran Ikan Cakalang di Kabupaten Halmahera Selatan. JIA (Jurnal Agribisnis Indonesia), 9(2), 105-121. https://journal.ipb.ac.id/index.php/jagbi/article/view/30970 